\title{
STAY OF PROCEEDINGS PENDING ARBITRATION: PROTECTING THE INTERESTS OF THIRD-PARTIES TO ARBITRATION IN NIGERIA
}

\author{
Taofeeq N. Alatise*
}

\begin{abstract}
Courts have the power to stay proceedings pending arbitration. In Nigeria, the enabling statute regulating commercial arbitration is the Arbitration and Conciliation Act of 1988. Sections 4 and 5 of the Act contain two similar but conflicting provisions regulating the stay of proceedings. These sections of the law are a product of a common ground found in two different legislative texts. While section 4 leveraged on the provision of Uncitral Model Law on Arbitration, section 5 is influenced by Arbitration Act of 1914. This dichotomy between the histories of the two sections partly accounts for the controversies and difficulties in the interpretation and application by courts and scholars. This article examines the scope of sections 4 and 5 of the Act by identifying the real object of the law and the flaws in its current interpretation. The article considers the American experience, especially, the attitude of courts in granting a stay of proceedings and whether a stay can be granted in a suit against a non-party to the arbitration agreement. Unlike arbitration laws in the United States, one key gap in Nigerian arbitration law is its failure to contemplate stay of proceedings in a suit against a non-party to an arbitration agreement. In addition to identifying the need for urgent legal reforms that accommodate third-party stay pending arbitration, this article recommends that Nigerian courts, like their counterparts in developed jurisdictions, should adopt a more proactive approach by evolving innovative ways in deciding suits involving third parties to arbitration agreement and stay proceedings pending arbitration in appropriate cases to prevent parties from avoiding arbitration by suing a third-party, in line with the global best practices.
\end{abstract}

Keywords: Arbitration, Stay of Proceedings, Third Party.

DOI: https://dx.doi.org/10.4314/jsdlp.v9i2.11

* LL.M (Ilorin) Legal Practitioner based in Ilorin, Kwara State, Nigeria. Email: alatise.taofeeq@yahoo.com 


\section{INTRODUCTION}

The relationship between national courts and arbitral tribunals is considered to oscillate between forced cohabitation and true partnership. ${ }^{1}$ Much as arbitration de-emphasizes resort to court, it is seen "to depend on the underlying support of the courts which alone have the power to rescue the system when one party seeks to sabotage it."2 Emphasizing this view, Lord Mustil reasoned as follows:

[T] here is plainly a tension here. On the one hand[,] the concept of arbitration as a consensual process reinforced by the ideas of transnational leans against the involvement of the mechanisms of state through the medium of a Municipal court. On the other side[,] there is the plain fact, palatable or not, that it is only a court possessing coercive powers which could rescue the arbitration if it is in danger of foundering. ${ }^{3}$

One of the ways through which courts support arbitral tribunal is judicial intervention in the conduct of arbitration, either before, during or after the arbitral proceedings. Clearly, the power of the court to grant a stay of proceedings pending arbitration is one of the ways of judicial intervention sanctioned by the Arbitration and Conciliation Act 1988 (the Act). ${ }^{4}$

Where provision is made in an ordinary arbitration agreement and proceedings are brought in a law court in respect of a matter, which is the subject of the arbitration agreement, the proper remedy is an application for a stay of proceedings. ${ }^{5}$ When parties have entered into an arbitration agreement, the usual issue is whether they can refer any dispute arising from such agreement to the court for determination. ${ }^{6}$ It

1 Alan Redfern and M. Hunter, Redfern And Hunter on International Commercial Arbitration (5th ed., Oxford University Press, 2009) 439.

2 ibid.

3 Coppee Levelin NVv. Kenren Fertilizers and Chemicals [1994] 2 L1oyd's Rep 109 at 116 (HL).

4 Arbitration and Conciliation Act. Cap A18 2004 (hereinafter referred as the "Act").

5 O. Adekoya and D. Emagun, Arbitration Guide IBA Arbitration Committee (Nigeria, 2012) 3.

6 A. Tweeddale and K. Tweeddale, Arbitration and Commercial Disputes (Oxford University Press, London, 2007) 288. Also, P. O. Idornigie, Commercial Arbitration Law and Practice in Nigeria (Panaf Press, Abuja, 2015) 266. 
has become commonplace that a party to an arbitration agreement might decide to institute an action in a court, rather than resort to arbitration, but the respondent usually insists on its right to have the dispute decided by arbitrators rather than national courts. ${ }^{7}$ The accepted standard sanctioned by the national laws is that most courts are prepared to enforce the arbitration agreement to arbitrate, by refusing to accept any proceedings in court and by referring the parties instead to arbitration. ${ }^{8}$ In Nigeria, there is a legal regime in favour of arbitration as provided in Sections 4 and 5 of the Arbitration and Conciliation Act. Nigerian courts, like their counterparts in other jurisdictions, have a legal duty to enforce arbitration agreement by staying proceedings and referring parties to arbitration.

However, over the years, the crisis of interpretation has continued to inhibit the application of the relevant provisions of the law on a stay of proceedings pending arbitration. Sections 4 and 5 of the Act deal with a stay of proceedings, even though they demand different considerations. While it is seen that section 4 of the Act takes away the discretion of the court in granting stay, Section 5 allows the court to exercise some discretion in the process, and since national courts value discretion, Nigerian courts have shown complete preference for section 5 of the Act in granting or refusing to stay proceedings pending arbitration. Indeed, it has been argued that under section 4 of the Act, stay of proceedings can be granted even in a suit instituted against a third party who is not a party to the arbitration agreement. While this position is strange under the Nigerian Arbitration laws, it is not so in other jurisdictions. The underlying issue is that parties to arbitration agreement might want to undermine arbitration by not only instituting matter in court, but also by suing a third party based on the same facts covered by the arbitration agreement.

This article examines the scope of section 4 and 5 of the Act by identifying the real object of the law and the flaws in its interpretation. It considers the American experience, especially the attitude of American courts to granting a stay of proceedings and examines whether a stay can be granted in a suit against a non-party to the arbitration agreement. The author finds that contrary to the views in some quarters,

7 Alan Redfern and M. Hunter, Law and Practice of International Commercial Arbitration (4th ed., Sweet and Maxwell, 2004) 331.

8 ibid. 
there is no legal regime of third party application for stay of proceedings in Nigeria, and this explains the attitude of Nigerian courts towards the idea. This prevailing attitude and regime would stifle the development of arbitration, especially in a commercial transaction. The author suggests a number of reforms, top of which are the amendment of the Nigerian arbitration laws to create a regime of third party right in stay of proceedings; the need for the Nigerian courts to adopt a pragmatic, proactive and a more imaginative approach when considering the issue, as is being done in other jurisdictions, especially in United States and United Kingdom; and the need for parties to promote third-party right at the contract stage.

To achieve this, the article is organized into five sections. After this introduction, section 2 of this article examines the scope of sections 4 and 5 of the Act by identifying the real import of these provisions. It further considers the controversy trailing the interpretation of "taking step in the proceedings" in the application for stay pending arbitration and observes that courts have refused to grant a stay in a number of cases because of its contentious nature. It also highlights the divergence of views on the existence of Sections 4 and 5 of the Act and how these debates have continued to shape the attitude of courts. Section 3 of this article analyses the place of a third party in the application for stay of proceedings and observes that though third party stay pending arbitration is not envisaged under the Nigerian laws of arbitration, it is a prominent feature of other jurisdictions, like America and the United Kingdom because of the approaches of courts in those jurisdictions. Section 4 of this article recommends required urgent reforms of the existing laws, the need for an imaginative approach by the courts; and the contractual recognition of third party right to stay proceeding as ways forward for addressing extant gaps in Nigerian arbitration framework. Section 5 is the conclusion.

\section{DECONSTRUCTING THE COMPASS OF SECTION 4 AND 5 OF THE ACT}

Sections 4 and 5 of the Act empower Nigerian courts to stay proceedings pending arbitration when a party seeks to undermine arbitration by instituting matter in court. So, clearly, there is a legal regime in favour of arbitration in Nigeria. There is no doubt that the provisions of sections 4 and 5 of the Act deal with a stay of proceedings. Section 4 provides that: 
"(1) A court before which an action which is the subject of an arbitration agreement is brought shall, if any party so requests not later that submitting his first statement on the substance of the dispute, order stay of proceedings and refer the parties to arbitration.

(2) Where an action referred to in subsection (1) of this section has been brought before a court, arbitral proceedings may nevertheless be commenced or continued and an award may be made by the arbitral tribunal while the matter is pending before the court."

And Section 5 of the Act provides that:

"(1) If any party to an arbitration agreement commences any action in any court with respect to any matter which is the subject of an arbitration agreement, any party to the arbitration agreement may, at any time after appearance and before delivering any pleadings or taking any other steps in the proceedings, apply to the court to stay the proceedings.

(2) A court to which an application is made under sub-section (1) of this section may, if it is satisfied - (a) that there is no sufficient reason why the matter should not be referred to arbitration in accordance with the arbitration agreement; and (b) that the applicant was at the time when the action was commenced and still remains ready and willing to do all things necessary to the proper conduct of the arbitration, make an order staying the proceedings."

Section 4 of the Act quoted above is the same as Article 8 of the UNCITRAL Model Law on International Commercial Arbitration, though with some modification, while section 5 is a "cut and paste" of the Arbitration Act of $1914 .{ }^{10}$ Some scholars have observed that there is a serious incompatibility between the sections and it has been suggested that this calls for an immediate amendment. ${ }^{11}$ First, the implication of

9 By this phrase it is meant that the Arbitration Act of 1914 is no longer extant as it has undergone series of repeals, culminating into the present Act.

10 Idornigie (n 5) 267. Also Gadzama, "Stay of Court Proceedings Pending Arbitration" in Arbitration \& Alternative Dispute Resolution in Africa, (ed.) C. J. Amasike, (The Regent Printing \& Publishing Ltd. 2005) 77.

11 Gadzama, (n. 11) 77; Olorunfemi, "Reconciling the Seeming Conflict in Sections $4 \& 5$ of the Nigerian Arbitration and Conciliation Act" (2011-2012) The Nigerian Judicial Review, Vol. 10, 155. 
section 4 is that a party seeking a stay of court's proceedings must do so before, or at any time of filing his pleadings, not thereafter. ${ }^{12}$ Section 4 also gives wider room for the applicant to move to stay the proceedings, and it is mandatory for the court to grant the application when it is properly made. ${ }^{13}$ On the other hand, section 5 "represents a compromise between advocates of a freely enforceable regime based on parties' agreement and those who wished to reject the enforceability of arbitration agreements because it "robbed" the court of its jurisdiction and influence". ${ }^{14}$ It appears to have been drafted to recognize the fact that though arbitration agreement exists, parties may still choose to litigate. ${ }^{15}$

It has been argued that Section 5 applies only to an action brought by a party to an arbitration agreement in respect of any matter, which is the subject of an arbitration agreement, and that unlike section 4, the application under section 5 is limited in scope since a party can invoke it to an arbitration agreement only against an action instituted by another party to the arbitration agreement. ${ }^{16}$ It has been observed that the wide meaning ascribed to "taking steps in the proceedings" and the two conditions prescribed under section 5 (2) can put spanners in the wheel of an application for a stay, which can only be granted at the discretion of the court. ${ }^{17}$

There has been a legion of judicial authorities suggestive of the fact that the grant of a stay is discretionary in all cases. ${ }^{18}$ Idonigie observed that this is not the position of the law. He added that the confusion was as a result of the Supreme Court decision in Kano State Urban Development case which, according to him, was decided based on section 5 of the Arbitration Law. ${ }^{19}$ It is instructive to point out that

12 Idornigie, (n 6) 267. Gadzama however stated that the applicant can also do so at the time of filing his pleadings, and not later than that. See Gadzama (n 8) at 80.

13 J. F. Olorunfemi, "Reconciling the Seeming Conflict in Sections 4 \& 5 of the Nigerian Arbitration and Conciliation Act" (2011-2012)The Nigerian Judicial Review, Vol. 10, 155.

14 O. O. Olatawura, "Stay of Proceedings in Nigerian Law of Arbitration: An Analysis of Its Functions, Problems, and Applications".

15 Ibid.

16 Olorunfemi, (n 14) 156.

17 Idornigie, (n 5). 269 See also the Case of Kano State Urban Development Board v. Fanz Construction Co. Ltd. [1990] 4 (NWLR) (Pt. 142) 1 at 50.

18 ibid.

19 Cap 7, Laws of Northern Nigeria, 1963. This law is a cut and paste of section 5 of Arbitration and Conciliation Act. 
almost all the cases decided after the Kano State Urban Development case were based on section 5 of the Act, and this is so because by virtue of the doctrine of judicial precedent, Nigerian courts are bound by the decision of the Supreme Court. For instance, a research conducted by this writer revealed that a total of about 10 cases were decided on a stay of proceedings from 2006 to 2017, and interestingly, they were all decided based on Section 5 of the Act, indicating a growing preference for Section 5 of the Act by the Nigerian Courts. ${ }^{20}$

A cursory look at section 4(2) of the Act would reveal that arbitration proceedings can be commenced and continued and award made by the arbitral tribunal while the legal action is pending before the court. However, Gadzama queried the rationality behind the provision of section 4(2) of the Act because "the Conundrum pertaining to this provision is that if the matter commences both at the arbitral tribunal and the Court, and the matter on technical ground is dismissed in the court, what would be the effect of the arbitral award?"21 While this is a genuine concern, our answer to this is that since an arbitral award is an outcome of an arbitral proceeding, its effect is not in any way diminished on the basis that a pending action is dismissed by the court. The successful party can enforce the award while the other party can as well apply to set aside the award. Besides, once an arbitral tribunal has decided the matter and an award has been reached, the matter pending before the court becomes an academic issue, which can be struck out.

Another fundamental issue is what amounts to taking step for the purpose of application of stay of proceedings pending arbitration. The fact that Nigerian courts have refused to stay proceedings in many

20 The research was conducted using the Nigerian Weekly Law Reports Between 2006 and 2017. Specifically the cases are: Enyelike v. Ogololma (2008) 14 NWLR (Pt. 1107) 247; Onward Ent. Ltd. v. Mo "Matrix" [2010] 2 NWLR (Pt. 1179) 530; O.K.S.M.H. v. M.I.E.E. (2012) 3 NWLR (Pt. 1287) 258; Statoil (Nig.) Ltd. v. N.N.P.C. [2013] 14 NWLR (Pt. 1373) 1; S.A. \& Ind. Co. Ltd. v. Ministry of Finance Incorp. [2014] 10 NWLR (Pt. 1416) 515; R.C.O. \& S. Ltd. v. Rainbowned Ltd. [2014] 5 NWLR (Pt. 1401) 516; B.C.N.N. v. Backbone Tech. Net. Inc. [2015] 14 NWLR (Pt. 1480) 511; Onyekweluye v. Benue State Government [2015] 16 NWLR (Pt. 1484) 40; Neutral Proprietary Ltd. U.N.I.C. Ins. Plc [2016] 5 NWLR (Pt. 1505) 374.

21 Gadzama, Stay of Court Proceedings Pending Arbitration' in Arbitration \& Alternative Dispute Resolution in Africa, Edited by C. J. Amasike, (The Regent Printing \& Publishing Ltd. 2005) 77. 
cases based on what amounts to taking step means that the issue remains contentious and uncertain.

\section{1 "Taking Step in the Proceedings" Clause and the Controversy of Interpretation}

One issue that has remained recurrent when interpreting section 5 of the Act is the meaning of "taking step in the proceedings". What is clear from the legion of judicial authorities is that the phrase does not have a one-size-fits-all approach; it depends on the circumstance of each case. ${ }^{22}$ Where an application for stay of proceedings is brought under section 5 of the Act, the applicant must not take a step other than appearance before applying. ${ }^{23}$ The Nigerian Supreme Court has held that "in order to get a stay, a party to a submission must have taken no step in the proceedings". ${ }^{24}$ What constitutes "taking step" also came up in the case of K.S.U.D.B v. Fanz Const. Ltd. ${ }^{25}$ In this case, the Supreme Court held that an application for pleadings to be filed constitute taking step and as such a contravention of Section 5 of the Arbitration Law.

Candide-Johnson and Shasore ${ }^{26}$ relying on the decision of the Supreme Court in the case of Obembe $v$. Wemobod Estate Ltd, ${ }^{27}$ submitted that "any act done in furtherance of the prosecution of the defence" can be said to amount to "taking step" in the proceedings". What is clear from all these is that apart from entering an appearance, the applicant must not have done anything before applying for a stay of proceedings.

Scholars have identified some instances that amount to taking steps in which case the court would be reluctant in granting a stay. ${ }^{28}$ Gadzama $^{29}$ enumerated some of these instances to include:

22 See Idornigie, (note 5) 267.

23 Section 5(1) of the Act.

24 Obembe V. Wemobod Estate Ltd. [1977] 5 SC 115 at 132, Per Fatayi-Williams

25 [1990] 4 NWLR (Pt. 142) 1.

26 C. A. Candide-Johnson and O. Shasore, "Commercial Arbitration Law and International Practice in Nigeria" (Lexis Nexis, 2012) 131.

27 (1977) 5 SC 115.

28 Idornigie (n. 5) at 268, Candide-Johnson and Shasore, n. 25 at 127 to 130.

29 Gadzama (n 23) at 79. 
(1) Where the applicant applies to the court for pleadings to be ordered. ${ }^{30}$

(2) Where the applicant appeared in court and asked for an order to strike out another party joined as a defendant from the suit.

(3) Where an applicant applies for an adjournment to enable him to file a statement of defence.

(4) Where the applicant defended the action without asking for stay but later in the proceedings challenged the plaintiff's right to bring the action. ${ }^{31}$

(5) Where the applicant entered a defence and in it indicated that at the hearing he would rely on the arbitration clause.

(6) Where defence has been entered, but later in the proceedings, the defendant applied for an order to dismiss the case so that arbitration could take place. ${ }^{32}$

(7) Where the defendant filed a counter-claim or a notice of his intention to counter-claim.

(8) Where the defendant defended the action and in his amended statement of defence contended that the plaintiff's action could not be sustained because he did not resort to arbitration.

In all these instances and many more, the court would not grant a stay of proceedings as the applicant would be regarded to have taken a step and as such waved his right to arbitration. The reason for the strict attitude of the Nigerian court is that the right to apply for a stay of proceedings is not a constitutional right, but a personal right of a party to the arbitration agreement. And so, where a party fails to apply for a stay before taking a step, the party will be deemed to have waived his right to go into arbitration, and a court will fully assume jurisdiction as if there was no arbitration agreement between the parties in the first place. ${ }^{33}$ It has been stated that the delivery of a counter-claim amounts to bringing an action when the subject matter of the counter is one the parties have agreed to refer to arbitration. ${ }^{34}$ A stay may be

30 Kano State Urban Development Board v. Fanz Construction Co. Ltd. [1990] 4 NWLR (Pt. 142) 1 at 50.

31 Chemical Products (UK) Ltd, v. Idowu [1963] 2 ALL NLR 249.

32 Achonu v National Employers and Insurance [1971] 1 ALR Comm. 449.

33 R.C.O. \& S. Ltd. v. Rainbowned Ltd. [2014] 5 NWLR (Pt. 1401) 516.

34 Candide-Johnson and Shasore (n 28), 127. 
approved for the claimants provided they have not taken a step in the proceedings or filed a "statement on the substance" after the delivery of the counter-claim. ${ }^{35}$

\subsection{Can a Claimant Apply?}

One issue that remains unclear is whether the Claimant can apply for a stay of proceedings pending arbitration. The point is that in this era of frontloading system, where a claimant is required to file his statement of claim along with the originating processes, is it permissible for the claimant to apply for a stay? Will that not amount to taking step on the part of the claimant? The Act obviously does not contemplate a situation where the party who institute a matter in court in breach of an arbitration clause will want to apply for a stay. Section 5 of the Act provides that where a party to an arbitration agreement institutes a matter in court "any party to the arbitration agreement may, at any time after appearance and before delivering any pleadings or taking any other steps in the proceedings, apply to the court to stay the proceedings". From the tenor of section 5 of the Act, it is clear that the party referred to is the party sued by the claimant, the defendant. Indeed, the reference to appearance and delivering any pleadings or taking any step has all the features of a party intending to defend a suit already in court. It, therefore, means that the entire section 5 of the Act only relates to the defendant who is being sued on a matter that is subject to the arbitration agreement and also intends to apply for a stay. Does that mean that a claimant cannot apply for a stay? If the Claimant can, will he be bound by the provision of section 5 of the Act?

To resolve this issue, the case of K.S.U.D.B v. Fanz Const. Ltd. would be helpful. In this case, the Supreme Court observed that the statement of claim of the plaintiff was filed long before the plaintiff's application to refer the matter to arbitration was made and also before the order of stay was made by the Court, and, as such, the court is deprived of the jurisdiction to stay the proceedings. This perhaps would suggest that having filed his statement of claim, the plaintiff cannot apply for the matter to be stayed. In order words, section 5 of the Act applies as well to a plaintiff. However, this may not be so. First, the reason why

35 Ibid. See also Confidence Insurance v. Trustees of Ondo State College of Education [1992] 2 NWLR (Pt. 591) 373. 
the Supreme Court held that the trial court that granted the stay had no jurisdiction to do so is not because the plaintiff who applied that the matter be referred to arbitration had filed his statement of claim, rather it is because of the defendant, who on the first day of appearance before the trial judge, applied that the pleadings be ordered. Delivering judgment on the issue, Agbaje, JSC., held:

[I]t appears to me having regard to the copious authorities on the point that an application for pleadings in court constitutes a step in the proceedings within the meaning of that expression in section 5 of the Arbitration law.

In his concurring judgment, Obaseki, JSC, held "even then, in contravention of the provision of section 5 of the Arbitration law, a step had been taken when the application for an order for pleadings to be filed was made". It, therefore, means that the above case does not establish the principle that the plaintiff or claimant can also apply for a stay. What then is the way out if a claimant who institutes a matter in a court in breach of arbitration agreement suddenly decides to explore arbitration? The best bet of the claimant is to seek the leave of the court to discontinue the action by withdrawing the suit either before receiving the processes of the defendant or immediately after receiving such processes, but before taking any other proceedings in the action. This position is sanctioned by the civil procedure rules of most of the State High Courts ${ }^{36}$ and the Federal High Court. ${ }^{37}$ The implication of such withdrawal is that the suit will be struck out and, of course, subject to the order as to the payment of cost to the defendant. If this is achieved, the coast would be clear for the claimant to go into arbitration with the defendant as such withdrawal will not be a "defence to a subsequent action for the same or substantially the same cause of action by the claimant". ${ }^{38}$

36 See Order 31 Rule 1 of Kwara State High Courts Civil Procedure Rules, 2005; Order 23 Rule 1(1) and 2(2) of the Lagos State High Courts Civil Procedure Rules; Order 29 Rule 1, 2 and 3 of Kano State High Courts Civil Procedure Rules; Order 23 Rule 1 of Rivers State Civil Procedure Rules; and Order 11 Rule 1 of the Abia State High Courts Civil Procedure Rules.

37 Order 50 of the Federal High Courts Civil procedure Rules.

38 Ibid. 


\section{DIVERGENT PERSPECTIVES ON THE EXISTENCE OF SECTIONS 4 AND 5 OF THE ACT}

The existence of sections 4 and 5 in the Act dealing with a stay of proceedings has generated intense criticisms from scholars and practitioners. ${ }^{39}$ It is has been stated that section 4 should, because of its UNCITRAL model origin, be placed in the international arbitration sections of Cap A.18 LFN 2004. ${ }^{40}$ This position, however, ignores the fact that other provisions of the Model law also apply to domestic arbitration..$^{41}$ Olatawura agreed that section 4 is applicable to domestic arbitrations and certain international arbitrations where, had it not been the arbitration agreement, the court would normally have jurisdiction over the substantive suit. ${ }^{42}$

It has also been pointed out that "section 5 is a major threat to the advancement of arbitration law in Nigeria as it does not encourage but impedes the recourse to arbitration". ${ }^{43}$ Disagreeing with this position, Ezejiefor stated that "as between the two sections, section 5 is a better provision for the arbitral system. A situation in which every application for a stay must be granted may have an overwhelming effect on the arbitral process. ${ }^{44}$ Any party applying for a stay would, of course, prefer to come under section 4 than section 5 where the court is allowed to exercise some initiative in granting or refusing a stay. ${ }^{45}$ This position has been faulted on the ground that "the applicant is not bound to come under both sections, where he comes under section 4, as is most likely, it may be possible for the respondent to raise section 5 , thereby insisting that the conditions therein be satisfied before the stay may be granted. Whether the court of first instance regards section 5 as

39 Olatawura, (n. 15) 695.

40 A. O. Orojo and M. A. Ajomo, Law and Practice of Commercial Arbitration and Conciliation in Nigeria (Mbeyi Associates 1999) 320; G. Ezejiofor, (n. 19). See also, A. A. Olawoyin, Charting New Waters with Familiar Landmarks: The Changing Face of Arbitration Law and Practice in Nigeria, (2009) 26 J. Int. Arb. $3,373,388$.

41 Olatawura, n. 15 at 697.

42 Ibid.

43 Gadzama, (n. 22) 80.

44 G. Ezejiofor, The Law of Arbitration in Nigeria (Longman, 1997) 42.

45 O. D. Amucheazi, "Enforcing Arbitration Agreement in Nigeria" Unizik Law Journal, 4(1): 95. 
relevant in the circumstances, or if it does not, whether it finds that conditions exist for the exercise of its discretion against the applicant are issues which could be litigated up to the Supreme Court. ${ }^{46}$ Chukwuemerie observed that the presence of section 5 is "duplicitous and inexplicable", wondering why the drafters would create confusion in the Act. ${ }^{47}$ Dissatisfied with the way the stay of proceedings was provided, Asouzu says something should be done to clarify section 4 and its relationship with section $5 .^{48}$

Some people have argued that there is no relationship between sections 4 and 5 , as each section demands an exclusive interpretation. ${ }^{49}$ This position, however, ignores the wisdom in the age-long principle of not interpreting provisions of law dealing with the same subject in isolation. Both sections 4 and 5 regulate the stay of proceedings, and it is the duty of the court to give a communal reading to these sections to ascertain the real intention of the drafter. ${ }^{50}$

It has been asserted that section 4 is a challenge on the inherent discretion of the court to either grant or refuse an application made before it. The word "shall" in section 4 (1) is traditionally mandatory. ${ }^{51}$ Is it then a matter of "must" such that when the arbitration agreement is null and void, inoperative or incapable of being performed, the court would still grant the order? ${ }^{52}$ Our response to this is that under the principle of separability, the court is expected to stay proceedings to allow the arbitral tribunal determine whether the arbitration agreement is actually null and void, in deference with the age-long principle of competence-competence.

However, Olatawura observed that the conclusion following from the non-incorporation of the exact words used in Art. II (3), New York Convention 1958 and Art. 8 (1), Uncitral model law 1985 in Cap A. 18

46 Nduka Ikeyi, "The Courts and the Arbitral Process in Nigeria" (1997) ADRLJ 362-363.

47 A. Chukwuemerie, New Dimensions in Commercial and Oil \& Gas Laws (Lawhouse Books, 2007), 258-259.

48 A. Asouzu "The Arbitration and Conciliation Decree (Cap. 19) as a Legal Framework for Institutional Arbitration: Strengths and Pitfalls," a paper presented at the IBA: African Regional Conference, Lagos (February, 1995) (Unpublished). pp. 13-14

49 Olatawura, (n. 15) Olorunfemi (n. 14).

50 This is one the canons of interpretation recognized under the Common Law.

51 Olorunfemi (n. 14).

52 ibid. 
LFN 2004, that is where the agreement is null and void or incapable of being performed, is the deliberate legal policy to ease the mandatory application of section 4. If the Uncitral model 1985 policy were to be used, the grant of stay of proceedings would be delayed or frustrated by a litigant canvassing that the arbitration agreement is invalid, and the court so determining. ${ }^{53}$ What is clear is that the provision of section 4(2) may make the court's refusal to order a stay ineffective as the arbitral proceedings "may nevertheless be commenced or continued" and an award made by the arbitral tribunal may be binding on the party that has commenced an action in court. ${ }^{54}$

Be that as it may, since arbitration agreement does not oust jurisdiction of court, it, therefore, implies that Section 4(2) creates an additional facility to the defendant who is willing to arbitrate and an award arising therefrom would not be regarded as a usurpation of the judicial powers of the court on a pending action. ${ }^{55}$ These divergent views have shown the lack of clarity in the arbitration law of the country, thereby making amendment of the laws imperative.

\subsection{Stay of Proceedings and the Place of a Third Party in Nigeria}

Another interesting issue in the application of stay of proceedings is the position of law on whether a court can stay proceedings in an action instituted by a non-party to the arbitration agreement - third party. While arguments have continued to rage on this vexed issue, what is clear is that the term "party" to an arbitration agreement has been settled by statutes and case laws. It is instructive to note that the principle of party autonomy is the bedrock of arbitration. It remains to be seen how a non-party to an arbitration agreement will advance the cause of party autonomy. Acknowledging the power of the court to grant a stay in an action brought by a third party, it has been argued that section 4 of the Act contemplates a third party action because the said section does not limit the grant of stay only to action involving parties to the arbitration agreement. ${ }^{56}$ While this position is strange

53 Olatawura, (n 15) 700.

54 E. Akpata, The Nigerian Arbitration Law in Focus (West African Publishers, 1997) quoted in the Supreme Court case of The Owners of M. V. Lupex v. Nigerian Overseas Chattering \& Shipping Ltd. [2003] 15 NWLR (Pt. 844) 469.

55 Olorunfemi, note 14 at 168 .

56 Ibid. at 163. 
and curious, it does not represent the correct position of the Nigerian arbitration law. We shall contest the position and explicate our reasons later. In the meantime, we shall consider the arguments of the author.

According to the author, section 4 of Act is wider in scope and, as such, cannot be given a limited interpretation like section 5 of the same law. ${ }^{57}$ Analysing the relevant section of the law, the author argued:

[T] he relevant portion of section 4 reads, "A court before which an action which is the subject of an arbitration is brought..." while the corresponding portion of section 5 reads, "If any party to an arbitration commenced any action in any court with respect to any matter which is subject of an arbitration agreement..."

He added that that the difference between the two sections is clear. ${ }^{58}$ The author argued further, that "there is nothing in section 4 limiting its application to an action brought by a party to an arbitration agreement". Based on these analyses, the author concludes that:

[W] hile we agree that the applicant under section 4 must be a party to an arbitration agreement, the action which is the subject of arbitration agreement could have been brought by a third party. ${ }^{59}$

The author misconceived the position of the law on this issue. First, there is nothing in section 4 of the Act, either in form or substance, that permits a party to an arbitration agreement to apply for a stay of proceedings in action brought by a third party who is not a party to the arbitration agreement. For us, the operative word under section $4(1)$ of Act is, “... if any party so request ...". In our view, the interpretation of this phrase would resolve this contentious issue. In this light, what then is the meaning of a "party"? The Act has answered this question in its interpretation section - section 57 (1) of Act. For the avoidance of doubt, section 57(1) provides:

$[\mathrm{P}]$ arty means a party to the arbitration agreement or to conciliation or any person claiming through or under him and "parties" shall be construed accordingly.

It is clear from the provision of section 57 that only parties to an arbitration can apply for a stay. It is also not in doubt that a stay of

58 Ibid.

59 Ibid., 163. 
proceedings pending arbitration would only be granted in an action involving the parties to an arbitration agreement, not a third party. The author cited a foreign decided case ${ }^{60}$ in support of his position. It is our submission that the case was not decided on an analogous provision as obtained under section 4 of Act or even the Uncitral Model Law and even if it did - which we do not concede - such a decision is merely of persuasive effect. It is not surprising that the learned author could not cite any Nigerian case to support his argument; the reason is that such a third party action is not contemplated under the Act.

The question whether a third party can apply for a stay is the subject matter for determination in the case of A.I.D.C. v. Nigeria LNG Ltd. ${ }^{61}$ The issue for determination in the above case is, "whether the defendant, who is neither a party to the arbitration agreement nor a derivative party, is entitled to a stay of proceedings in an action brought on a guarantee". The facts of the case were that sometime in October 1990, the respondent entered into a contract with one Construction Company known as Fedison Nigeria Limited for the drilling of a water well at Bonny Island, Rivers State, Nigeria. The contract contained an arbitration clause. Also by a performance bond dated 21 December 1990, the contractor and the appellant (who stood as a Surety for the contractor for the completion of the contract) severally and jointly bound themselves to pay the respondent the sum of N538,122.00 in the event of default by the contractor. However, the appellant as the surety was not a party to the main contract between the respondent and the contractor, which contained an arbitration clause.

On 2 April 1991, the respondent terminated the contract with the contractor for failure of the contractor to complete the contract within the agreed period of time. Thereafter, the respondent sued the appellant (the Surety) for the application of the performance bond, claiming that the contractor did not duly perform, execute or complete the said contract within 91 days. The appellant then filed a motion on notice for a stay of proceedings pending reference to arbitration on the ground that the subject matter of the action was governed by an arbitration clause. Though the trial court granted the application and stayed proceedings on the ground that although the arbitration clause is not included in the performance bond, it ought to be read into existence by the main contract between the respondent and the contractor.

60 RGE (Group Services) v. Cleveland Offshore [1981] 11 Con. L.R. 77.

61 AIDC v. Nigeria LNG LTD [2000] 4 NWLR (Pt. 653) 494. 
Dissatisfied with the ruling of the trial court, the respondent appealed to the Court of Appeal contending that the trial court erred in staying the proceedings when the appellant was not a party to the arbitration agreement. Allowing the appeal, the Appellate court held that the appellant not being a party to the contract between the respondent and the contractor, the appellant could not rely on the arbitration clause in a contract to which it was not a party. The court further held that the appellant was not the proper party to apply for stay since dispute in arbitration means a dispute between the respondent and the contractor and not the appellant who is the surety of the contractor.

Aggrieved, the appellant appealed to the Supreme Court contending that he qualifies as a party to the contract, which contained the arbitration clause between the respondent and the contractor since he was the surety for the performance of the contract. Affirming the decision of the Court of Appeal, the Supreme Court, relying on the provision of Section 5 (1) of the Arbitration and Conciliation Act, the Nigerian Supreme Court held:

[I]t is evident from the provision of section 5(1), that the applicant for stay of proceedings must be a "party to the arbitration agreement" and that the subject matter of the action must be "with respect to any matter which is the subject of arbitration. ${ }^{62}$

What is clear from the decision of the apex court is that for a court to exercise its power to grant a stay, the applicant must not only be a party to an arbitration agreement, the subject matter of the action must be in respect of the arbitration agreement. With this decision of the Supreme Court, the opinion of the author has no leg to stand.

It could be argued that based on the principle of law in the cases of Shell Nigeria Exploration and Production Ltd. v. Federal Inland Revenue Service; ${ }^{63}$ and Statoil (Nig.) Ltd. v. Federal Inland Revenue Service, ${ }^{64}$ a non-party to an arbitration agreement can challenge arbitral proceedings. In both cases of Shell and Statoil, the Court of Appeal affirmed the standing of the Federal Inland Revenue Service (FIRS) to institute an action to challenge the jurisdiction of the arbitral tribunal, even though FIRS was not a party to the arbitration agreement. It is

62 AIDC v. Nigerian LNG Ltd [2000] 4 NWLR (Pt. 653) 494 at 504.

63 (Unreported) CA/A/208/2012 delivered on 31st August, 2016.

64 [2014] LPELR - 23144. 
our view that both Shell and Statoil cannot be an authority validating third-party action and application for stay of proceedings. First, those cases were not decided on the basis of section 4 and 5 of the Act dealing with an application for stay of proceedings pending arbitration, but on section 251 of the Constitution ${ }^{65}$ dealing with the arbitrability of tax disputes.

Second, the only reason why the court recognized the standing of FIRS is simply because the dispute is tax-related and, as such, it will impact on the power of FIRS, a statutory body saddled with the function of assessing, collecting and accounting for taxes under relevant tax legislations. Indeed, it has been observed that allowing a no-party to challenge arbitral proceedings will be contrary to the idea of party autonomy, a principle at the heart of the concept of arbitration.

While the position above describes the Nigerian situation, it is not so in other jurisdictions, especially in the United States.

\subsection{The American Perspective}

In the United States, there is a federal policy in favour of arbitration so that when a contract between parties made reference to arbitration, American courts have a duty under the law to stay proceedings and refer parties to arbitration. ${ }^{66}$ Unlike Nigeria, in America, the arbitration law is not based on the Uncitral model law. ${ }^{67}$ The law governing arbitration in United States is the Federal Arbitration Act (FAA). ${ }^{68}$ Enacted in 1925, the FAA regulates arbitration proceedings in America. The FAA actually predates the Unctral model law on arbitration. Again, all the fifty States in the United States have adopted their own arbitration statutes based on the Uniform Arbitration Act of 1955.

In the United States, where a plaintiff ignores the arbitration contract and files suit in a court of law, a defendant can either request a court to grant a stay of the suit pending arbitration as regulated by

651999 Constitution of Nigeria (as amended).

66 A. R. Johnson, “Oh, Won't You Stay With Me?: Determining Whether $\S 3$ of the FAA Requires A Stay in the Light of Katz V. Cellco Partnership" (2016) Fordham Law Review 84(5) 2266.

67 M. W. Friedman and F. Lavand Arbitration Guide: IBA Arbitration Committee: United States (Updated January 2018)https://www.ibanet.org/Document/ Default.aspx?DocumentUid=939CE0D4-8D8A-4350-81D7-B7FEFE923C11 accessed on 19 February 2018.

68 ibid. 
section 3, or file a motion to compel arbitration of the dispute under the FAA section 4 or seek both types of reliefs. ${ }^{69}$ In such instance, the court has a power to "stop a lawsuit begun by the party resisting arbitration ..." $" 70$ and refer parties to arbitration, in line with the federal policy in favour of arbitration. It has been noted that this power to refer parties to arbitration is not limited only to parties to the arbitration agreement. ${ }^{71}$ Usually, parties to arbitration agreement try to avoid arbitration by suing non-parties to the arbitration agreement and claiming damages that are directly or indirectly arising from the arbitration agreement. ${ }^{72}$ In such situation, such a non-party to the arbitration agreement may be entitled to compel arbitration, or simply urge the court to stay the claims pending arbitration between the parties to the arbitration pursuant to Section 3 of FAA. Section 3 of the FAA regulates stay of proceedings pending arbitration. It provides:

[I]f any suit or proceedings be brought in any of the courts of the United States upon any issue referable to arbitration under an agreement in writing for such arbitration, the court in which such suit is pending, upon being satisfied that the issue involved in such suit proceeding is referable to arbitration under such an agreement, shall on application of one of the parties stay the trial of the action until such arbitration has had in accordance with the terms of the agreement, providing the applicant for the stay is not in default in proceeding with such arbitration.

The term "parties" has been interpreted by the Supreme Court of United States to mean parties to the litigation rather than parties to the contract, and as such "a litigant who is not a party to the relevant arbitration agreement may invoke Section 3 if the relevant state contract law allows him to enforce the agreement". ${ }^{73}$ The Supreme Court of the United States has acknowledged that "Traditional principles of state

69 A. M. Petti, "Judicial Enforcement of Arbitration Agreements: The Stay-Dismissal Dichotomy of FAA Section 3" (2005) Hofstra Law Review, 34 (2) 569.

70 Matterhorn, Inc. v. NCR Corp., 763 F.2d 866, 871 (7th Cir. 1985) Posner, J.

71 O. J. Hill. Stay Pending Arbitration of Claims Made Either By or against NonParties to Arbitration Agreement, <https://www.americanbar.org/publications/ under_construction/2014/march_2014/stay_pending_arbitration_claims. html> accessed 09 May 2018.

72 O. J. Hill (n 68). See Arthur Andersen LLP v. Carlisle, 556 U.S. 624, 630 n.4 (2009).

73 Arthur Andersen LLP v. Carlisle [2009], 556 U.S. 624, 633. 
law allow a contract to be enforced by or against non-parties to the contract through assumption, piercing the corporate veil, alter ego, incorporation by reference, third-party beneficiary theories, waivers and estoppel...". ${ }^{74}$ So the implication of this is that a non-party to the arbitration agreement can compel arbitration if the claims make reference to, or arise out of a written agreement requiring arbitration, or when the claims against the non-party are inextricably intertwined with claims against a party to the arbitration agreement. ${ }^{75}$ This is in line with the federal policy favouring arbitration.

The key factor courts always consider is whether the non-party potential liability derives from the conduct or potential liability of a party, such that staying claim against the non-party would conserve judicial resources and minimize the possibility of inconsistent rulings. ${ }^{76}$

American courts are conscious of the fact that if a party to the arbitration agreement is allowed to avoid arbitration by suing a third party, say a surety or guarantor, such a result would effectively render arbitration provisions meaningless. For instance, where a party to a construction agreement containing arbitration clause decides to sue the surety in order to avoid arbitration with the other party to the agreement, it is within the right of the surety to urge the court to stay proceedings so that the actual parties to the arbitration agreement can go into arbitration because the liability of the surety depends on whether there has been a breach of the contract between the parties to the agreement. The attitude of the court is that in such situation there is no reason to duplicate the determination and risk inconsistent rulings that will also undermine the arbitration between the signatory parties. ${ }^{77}$

Evidently, in the United States, the courts are more inclined to grant a stay in line with the federal policy in favour of arbitration, especially when it appears that a party is trying to avoid arbitration by suing a non-party to the arbitration agreement. Section 3 of the FAA empowers the courts to stay proceedings even on the application of the non-party to the arbitration agreement. In Nigeria, the situation is quite different because the definition of who is a party appears to have been settled, statutorily and judicially. Nigerian courts with a rich

74 Ibid at 631.

75 See Field System Machining, Inc. v. Vestas-American Wind Technology, Inc. [2013] WL 1943307, 4 (N.D. III. 2013).

76 See Petrik v. Reliant Phamaceuticals, [2007] WL 3283170 (M.D. Fla. 2007).

77 See Kroll v. Doctor's Associates, Inc., 3 F.3d. 1167, 1171 (7th Cir. 1993) 
common law tradition interpret the law as it is, especially when the words are clear and unambiguous.

Even in the United Kingdom, exceptional circumstances abound where the English courts exercise their discretionary powers to stay proceedings pending arbitration where a third party is involved. It has been observed that English courts have accepted that a court has "inherent jurisdiction" to stay its own proceedings where the action depends upon the outcome of an arbitration between either the same or different parties. ${ }^{78}$ For instance, where a creditor brings judicial proceedings against the guarantor in advance of the determination of the debtor's liability in ongoing arbitration proceedings. This power, though rarely exercised, was recognized in the famous case of Reichhold Norway ASA v. Goldman Sachs International. ${ }^{79}$ There has been little development in this area by the Nigerian courts.

\section{RECOMIMENDATIONS}

Nigerian arbitration laws have not witnessed many improvements over the years, leaving fundament issues of arbitration practice unattended to. The need to revolutionize the practice of arbitration in Nigeria and open the arbitration space for a more inclusive participation, especially in commercial transactions, is all the more imperative given the exponential growth in the adoption of arbitration as an effective alternative to litigation. One of these issues is the place of a non-party in the application of stay of proceedings. Going forward, the view of this writer is that granting a third party right to stay proceedings would fundamentally improve the practice of arbitration in the country. In this light, the article makes the following suggestions:

\subsection{Creating a Legal Regime of Third Party Right}

It is the law of the land that defines the scope and limit of an Act. Putting in place a legal framework that recognizes the right to stay proceedings in a suit involving non-party to arbitration agreement is the most potent way of sanctioning third-party right. While it can validly

78 Stay of Judicial Proceedings: Case Management Stays < https:// www.arbitrationlawmonthly.com/reliefs-and-remedies/stay/stay-of-judicial79 ibid. proceedings-case-management-stays-1.htm> accessed 15 March 2018. 
be argued that this reform is unnecessary because even in many advanced jurisdictions there is no such express legal recognition of third party right to stay arbitration proceedings, the view of this writer is that an express legal recognition of third party right to stay proceedings in Nigerian arbitration laws would not only establish certainty in the practice of arbitration, but also create legal basis for Nigerian courts to affirm the existence of such right.

The same thing can be achieved through the amendment of the present Section 5 (1) of the Act by replacing "any party to the arbitration agreement may ..." with "any party to the proceedings may...". This amendment would enable a surety or guarantor or any person not directly party to the arbitration agreement but have an interest in the dispute covered by the arbitration agreement to be able to apply to stay proceedings pending arbitration between the parties to the arbitration agreement. The argument of the third party would be that his liability or otherwise depends on the outcome of the arbitration between the parties to the arbitration agreement.

Nigeria can set the pace in this area of arbitration practice and become a reference point for other jurisdictions.

\subsection{Proactive Judicial Approach}

The saying that "even where there is a good law, a judge can make a hell out of it" reinforces the position of this writer that establishing a legal regime for third party right would not be enough after all. The situation is not any better where no such laws exist. The Nigerian courts, by the nature of their duties, have the capacity to expand the frontiers of arbitration practice in the country. The present unduly and restrictive approach of the courts is completely at odds, and does not reflect the growing judicial pragmatism, of their counterparts in developed jurisdictions.

For instance, a more proactive approach by the court would have allowed the appellant in A.I.D.C.I. case (being the surety to the contractor) to be able to apply to stay the proceedings between it and the respondent because such right to stay proceedings is not limited to the parties to the arbitration agreement but to the parties to the proceedings with claims directly or indirectly covered by arbitration agreement. The reason would have been that there is a need to stay proceedings between parties because the liability of the appellant is limited to a finding that there is a breach of contract between the respondent and the contractor, which has been agreed to be determined 
through arbitration, and there is no need for the court to hear the matter in order to avoid inconsistent rulings and to also prevent a party from avoiding arbitration by suing a non-party to the arbitration.

The writer would, therefore, suggest that Nigerian Courts should adopt a more imaginative approach in interpreting Section 5 of the Act to accommodate the right of a third party to stay proceedings pending arbitration. The practices in the United States and the United Kingdom have shown that judges can actually develop the law where there is no express legal regime. The court in those jurisdictions have accepted the practice of staying proceedings pending arbitration in action involving third party to the arbitration. It helps to avoid inconsistent rulings coming from the court and the arbitral tribunal. It also serves as a good case management technique for the court and ensure that parties to the arbitration do not undermine it by going after a third party.

\subsection{Contractual Recognition}

The concept of party autonomy is at the core of arbitration. It may be argued that allowing a third party to stay proceedings would amount to unacceptable interference in the principle of party autonomy. However, this is not the whole truth, especially when the role of a third party is considered in its true perspective. The jurisprudential essence of allowing a third party to stay proceedings pending arbitration is not to ensure the participation of the third party in the arbitration proceedings, which he is strictly not a party to; but to actually ensure that the real parties to the arbitration agreement do not avoid arbitration by suing a third party. Put differently, since the liability of the third party arises from the dispute between the parties to the arbitration agreement, it is only when the dispute between the parties, which they have agreed to resolve through arbitration, is arbitrated, otherwise, none of the parties to the arbitration agreement can institute action against the third party.

So, clearly a third party right to stay proceedings pending arbitration has a positive effect to encourage, galvanize and deepen the practice of arbitration in Nigeria. In the absence of a favourable legal regime for third-party right, the parties themselves can device a means of encouraging third-party right. They can achieve this by inserting a clause in the arbitration agreement that says "the arbitration agreement between them shall not affect the right of a third party under the arbitration agreement". 


\section{CONCLUSION}

The attitude of the Nigerian courts in refusing stay in proceedings against a non-party to the arbitration is likely to frustrate the growth of arbitration in the country, especially when a party intends to avoid arbitration by suing a non-party to the arbitration agreement. Nigeria too has a favourable climate in favour of arbitration because arbitration is recognized as a method of dispute resolution. Section 5 of the Act clearly makes provision for a stay of proceedings when a party institutes an action in court in violation of the arbitration agreement. However, parties to an arbitration agreement could frustrate arbitration by suing a third party as we have seen in the case of A.I.D.C. When this happens, the whole essence of arbitration is undermined.

The reforms suggested by this article are capable of resolving the present problem. An amendment of section 5 of the Act to gives room for third-party right to stay pending arbitration is a good step in the right direction. The paper has argued that even in the absence of a legal framework, the courts can adopt a more proactive and imaginative strategy that would open the arbitration space for third party. The experiences of other jurisdictions can be very helpful to the Nigerian courts. The parties to the contract containing arbitration agreement can as well include a clause recognizing a third party right. In a fastgrowing economy like Nigeria, a pro-arbitration policy by the government is capable of improving commercial activities and allaying the fears of foreign investors of any unfavourable legal regime in the country. 